\title{
Purification and Properties of NAD-dependent Lactic Dehydrogenases of Different Species of Lactobacillus
}

\author{
By F. GASSER,* M. DOUDOROFF AND REBECCA CONTOPOULOS \\ Department of Bacteriology and Immunology, University of California, \\ Berkeley, California 94720, U.S.A.
}

(Accepted for publication 30 April 1970)

\begin{abstract}
SUMMARY
Six nicotinamide adenine dinucleotide (NAD)-dependent lactic dehydrogenases, four specific for $\mathrm{D}(-)$ lactate and two specific for $\mathrm{L}(+)$ lactate have been purified from different Lactobacillus species. Four of these enzymes appeared to be pure by several criteria. Some of the physical and catalytic properties of these enzymes are described and compared with those previously reported for the D- and L-lactic dehydrogenases of Lactobacillus plantarum.
\end{abstract}

\section{INTRODUCTION}

The NAD-dependent lactic dehydrogenases of different species and subspecific groups of lactobacilli have been shown to differ not only in their specificity towards $\mathrm{D}(-)$ or $\mathrm{L}(+)$ lactate but also in their electrophoretic migration (Gasser, 1970). The D- and L-lactic dehydrogenases of Lactobacillus plantarum have been purified and studied by Dennis \& Kaplan (I960). In the present studies, the purification of several D- and L-lactic dehydrogenases from selected Lactobacillus strains is described and their properties are compared. The most highly purified preparations of these enzymes were used for the preparation of antisera. The immunological cross-reactions among the purified enzymes and crude enzyme preparations of other strains will be described in a subsequent paper.

\section{METHODS}

Bacterial strains and cultivation. The bacterial strains used in the present studies were chosen from among those previously examined for their complement of lactic dehydrogenases and the electrophoretic properties of these enzymes (Gasser, 1970). They included: Lactobacillus leichmannii NCDO 302 (ATCC 7830), L. fermenti CNRZ 236, L. jensenii $62 \mathrm{G}$, L. acidophilus (group III) AI 8 and L. acidophilus (group I) $65 \mathrm{~K}$. The cultures were grown anaerobically at $37^{\circ}$ in Io 1 . fermenters purged with a constant stream of gas $\left(95 \% \mathrm{~N}_{2}\right.$ and $\left.5 \% \mathrm{CO}_{2}\right)$. The medium used was that previously described by Gasser (1970), but supplemented with sodium acetate $(0.05 \%, \mathrm{w} / \mathrm{v})$ and dibasic ammonium citrate $(0.02 \%, \mathrm{w} / \mathrm{v})$ for the growth of all strains except $L$. leichmannii NCDO 302.

Preparation of crude extracts. Bacteria were harvested at the end of the exponential phase of growth, washed with $0.05 \mathrm{M}$-phosphate $\left(\mathrm{KH}_{2} \mathrm{PO}_{4}-\mathrm{Na}_{2} \mathrm{HPO}_{4}\right)$ buffer, $\mathrm{pH} 7$, resuspended in the same buffer (100 mg. $/ \mathrm{ml}$.) and disintegrated in $50 \mathrm{ml}$. batches for

* Permanent address: Institut Pasteur, 25, rue du Docteur Roux, Paris (XV), France. 
$30 \mathrm{~min}$. with a Raytheon I I KC sonic oscillator and then centrifuged at 4 for $30 \mathrm{~min}$. at $15,000 \mathrm{~g}$. The protein contents of the crude extracts ranged from 5 to $18 \mathrm{mg} . / \mathrm{ml}$., depending on the bacterial strain used.

Assays of lactic dehydrogenases. During the course of purification, assays of lactic dehydrogenase activity were made with $\mathrm{D}(-)$ or $\mathrm{L}(+)$ lactate as substrate and NAD as coenzyme. The activity was measured at $25^{\circ}$ with a Gilford model 2000 recording spectrophotometer by determining the initial rate of NAD reduction at $340 \mathrm{~nm}$. in a mixture ( $\mathrm{I} \mathrm{ml}$.) containing: tris- $\mathrm{HCl}$ buffer, $\mathrm{pH} 8,200 \mu$ moles; the lithium salt of either $\mathrm{D}(-)$ or $\mathrm{L}(+)$ lactate, $100 \mu$ moles; NAD, $2 \mu$ moles. The reaction was initiated by the addition of sufficient enzyme to give an increase in extinction $(E)$ of approximately 0.05 optical density unit during the first minute. The reaction was linear for at least 3 to $4 \mathrm{~min}$. at all steps of the purifications. In crude extracts, NAD oxidase activity inflected the progress curve after the first minute of the reaction. In all assays the initial rate of NAD reduction was measured during the first minute of the reaction.

After purification, enzyme activity was also measured with pyruvate as substrate by measuring the initial rate of oxidation of the reduced form of nicotinamide adenine dinucleotide (NADH) at $340 \mathrm{~nm}$. in the following mixture (I ml.): tris- $\mathrm{HCl}, \mathrm{pH} \mathrm{8,} 200$ $\mu$ moles; sodium pyruvate, $20 \mu$ moles; NADH, $0 \cdot 2 \mu$ moles. The reaction was initiated by the addition of enzyme.

One unit of enzyme was defined as that amount which reduced I $\mu$ mole of $\mathrm{NAD} / \mathrm{min}$./ $\mathrm{ml}$. or which oxidized I $\mu$ mole of $\mathrm{NADH} / \mathrm{min} . / \mathrm{ml}$. Specific activity is expressed as units/mg. protein.

pH Optima. The effect of $\mathrm{pH}$ value on enzyme activity was determined in trismaleic acid-sodium maleate buffers, $0.05 \mathrm{M}$ with respect to both tris and the total maleic acid + maleate content, and adjusted to the desired $\mathrm{pH}$ value with $\mathrm{NaOH}$.

Kinetic studies. The $K m$ values for lactate, pyruvate and $\mathrm{NADH}$ were estimated by the graphical method of Lineweaver \& Burk (1934). Reaction rates were determined at $25^{\circ}$ in tris-maleic buffer as described above at the optimum $\mathrm{pH}$ for each reaction and enzyme. NAD was used at $2 \times 10^{-3} \mathrm{M}$ for assays with lactate, and pyruvate at $2 \times 10^{-2} \mathrm{M}$ for assays with $\mathrm{NADH}$. For assays with pyruvate $\mathrm{I} \cdot 7 \times 10^{-4} \mathrm{M}-\mathrm{NADH}$ was used for the D- and L-lactic dehydrogenases of Lactobacillus acidophilus $65 \mathrm{~K}$ and the L-lactic dehydrogenase of $L$. acidophilus AI8. For other enzymes, I $\times 10^{-4} \mathrm{M}$ was employed.

Thermal stability. The relative stability of the enzymes to heat inactivation was tested by immersing small test-tubes containing $0.8 \mathrm{ml}$. of $6.6 \times \mathrm{IO}^{-2} \mathrm{M}$-tris- $\mathrm{HCl}$ buffer, $\mathrm{pH} \mathrm{8,} \mathrm{and} \mathrm{appropriate} \mathrm{amounts} \mathrm{of} \mathrm{enzyme} \mathrm{in} \mathrm{water} \mathrm{baths} \mathrm{at} \mathrm{various} \mathrm{temperatures,}$ cooling them rapidly to $0^{\circ}$ after $5 \mathrm{~min}$. of incubation, rewarming to room temperature and assaying the enzyme activity by the usual procedure using $\mathrm{D}(-)$ or $\mathrm{L}(+)$ lactate as substrate and NAD as coenzyme.

Protein assays. Protein was assayed by the method of Lowry, Rosebrough, Farr \& Randall (I95I) in the early and final steps of purification. During the course of purification (after removal of the nucleic acids) the concentration of protein was estimated spectrophotometrically using the formula:

$$
\text { Protein }(\mathrm{mg} .)=\left(E_{280 \mathrm{~nm} .} \times \mathrm{I} \cdot 5\right)-\left(E_{260 \mathrm{~nm} .} \times 0.75\right) .
$$

Electrophoresis. Polyacrylamide gel electrophoresis was performed according to the method of Davis (1964), using samples containing 60 to I $20 \mu \mathrm{g}$. of protein. 
Ultracentrifugation. The Beckman-Spinco Model E analytical ultracentrifuge was used at $59,780 \mathrm{rev} / \mathrm{min}$. with schlieren optics for the determination of sedimentation coefficients and at $20,4 \mathrm{IO} \mathrm{rev} . / \mathrm{min}$. with Rayleigh interference optics for sedimentation equilibrium studies. All centrifugations were carried out at $4^{\circ}$ in $0.0 \mathrm{I}$ M-phosphate buffer.

Immunology. Details of the preparation of antisera and of the procedure for the agar double diffusion technique will be reported in a subsequent paper. Immuno-electrophoresis experiments were conducted according to the method of Grabar \& Williams (1955), using an agar gel containing barbital buffer, $\mathrm{pH} 8(\mu \mathrm{m} .=0 \cdot \mathrm{I})$.

\section{Purification of the D-lactic dehydrogenases of Lactobacillus leichmannii, L. jensenii and L. fermenti}

In this and in all other enzyme purifications, the procedures were carried out at $0^{\circ}$.

Step I. After acidification of the crude extract to $\mathrm{pH} 5.5$ with acetic acid, a protamine sulphate solution $(2 \%, \mathrm{w} / \mathrm{v})$ was added slowly with stirring to a final concentration of $0.3 \%(\mathrm{w} / \mathrm{v})$. After $15 \mathrm{~min}$. the mixture was centrifuged and the pellet discarded. The ratio of extinction $(E)$ at $280 \mathrm{~nm}$. to that at $260 \mathrm{~nm}$. of the supernatant liquid increased from $c .0 .55$ to $0.8-0.9$ after this treatment.

Step 2. After adjustment of the $\mathrm{pH}$ to 7 , solid ammonium sulphate was added slowly to $50 \%$ saturation. After $2 \mathrm{~h}$. the mixture was centrifuged and the precipitate discarded. The ammonium sulphate concentration was increased to $85 \%$ saturation by the addition of solid ammonium sulphate and the mixture centrifuged after I $2 \mathrm{~h}$. The pellet was redissolved in a minimum volume of $0.05 \mathrm{M}$-phosphate buffer, $\mathrm{pH} 7$, and dialysed against the same buffer.

Step 3. The enzyme preparation was applied to a DEAE Sephadex A50 column equilibrated with $0.05 \mathrm{M}$-phosphate buffer, $\mathrm{pH}$ 7. The column was washed with $0.05 \mathrm{M}$ $\mathrm{NaCl}$ in the same phosphate buffer (2 void vol.) and the enzyme was eluted with a linear gradient concentration of $\mathrm{NaCl}$. The peak of eluted enzyme was obtained with $0.16 \mathrm{M}-\mathrm{NaCl}$ for Lactobacillus leichmannii, $0.17 \mathrm{M}$ for $L$. jensenii and $0.28 \mathrm{M}$ for L. fermenti.

Step 4. Peak tubes of enzyme were pooled and their contents submitted to the following treatments for further purification. (a) For Lactobacillus leichmannii and $L$. ferment $i$ the pool was precipitated with ammonium sulphate at $85 \%$ saturation and the amorphous precipitate was submitted to a back extraction procedure with decreasing concentrations of ammonium sulphate. The resulting enzyme solutions were allowed to stand at $0^{\circ}$ until what were presumed to be crystalline precipitates appeared. Those precipitates with the highest specific activity were pooled and repeatedly reprecipitated in the same manner to a constant specific activity. $(b)$ Because the enzyme of $L$. jensenii was unstable to repeated ammonium sulphate fractionation, it was treated differently. The pool of the peak tubes of enzymic activity from the DEAE Sephadex column was applied to a second DEAE Sephadex column and again eluted with a linear $\mathrm{NaCl}$ gradient. The tubes containing the enzyme peak from this second DEAE Sephadex column were pooled, the solution concentrated in a mechanical membrane concentrator (Diaflo, Amicon Corporation, Lexington, Massachusetts, U.S.A.) and then applied to a G-100 Sephadex column equilibrated at $\mathrm{pH} 7$ with $0.05 \mathrm{M}$-phosphate buffer containing $\mathrm{O}$. I M-NaCl. The enzyme was eluted with the same 
solution. Peak fractions with equivalent specific activity were pooled. Results using this procedure are summarized in Table $\mathrm{I}$.

\section{Separation and purification of the $D$ - and L-lactic dehydrogenases of Lactobacillus acidophilus $65 \mathrm{~K}$}

The L-lactic dehydrogenase of Lactobacillus acidophilus $65 \mathrm{~K}$ was very unstable both to the acidification involved in protamine sulphate treatment and to ammonium sulphate precipitation. The D-lactic dehydrogenase also proved to be unstable to repeated ammonium sulphate fractionation in the later stages of purification. Hence a procedure was devised by which the two enzymes were separated and partially purified with minimum use of these reagents.

Table I. Purification of D-lactic dehydrogenases of Lactobacillus leichmannii, L. fermenti and L. jensenii

\begin{tabular}{|c|c|c|c|c|c|c|c|c|c|}
\hline \multirow[b]{2}{*}{ Preparations } & \multicolumn{3}{|c|}{ L. leichmannii $\mathrm{NCDO} 302$} & \multicolumn{3}{|c|}{ L. fermenti CNRZ 236} & \multicolumn{3}{|c|}{ L. jensenii $62 \mathrm{G}$} \\
\hline & $\begin{array}{l}\text { Total } \\
\text { activity* } \\
\text { (units) }\end{array}$ & $\begin{array}{l}\text { Specific } \\
\text { activity } \\
\text { (units/mg. } \\
\text { protein) }\end{array}$ & $\begin{array}{l}\text { Yield } \\
(\%)\end{array}$ & $\begin{array}{l}\text { Total } \\
\text { activity* } \\
\text { (units) }\end{array}$ & $\begin{array}{c}\text { Specific } \\
\text { activity } \\
\text { (units/mg. } \\
\text { protein) }\end{array}$ & $\begin{array}{l}\text { Yield } \\
(\%)\end{array}$ & $\begin{array}{l}\text { Total } \\
\text { activity* } \\
\text { (units) }\end{array}$ & $\begin{array}{c}\text { Specific } \\
\text { activity } \\
\text { (units/mg. } \\
\text { protein) }\end{array}$ & $\begin{array}{l}\text { Yield } \\
(\%)\end{array}$ \\
\hline Crude extract & 84,700 & 5.5 & 100 & 68,800 & $7 \cdot 5$ & 100 & 35,600 & $2 \cdot 9$ & 100 \\
\hline $\begin{array}{l}\text { Supernatant after protamine } \\
\text { sulphate ppt. (step I) }\end{array}$ & 68,800 & $9 \cdot 7$ & $8 \mathrm{I}$ & 65,400 & $15 \cdot 6$ & 95 & 34,900 & $3 \cdot 24$ & 98 \\
\hline $\begin{array}{l}\text { Ammonium sulphate ppt. } \\
\text { (50 to } 85 \% \text { saturation) } \\
\text { (step } 2 \text { ) }\end{array}$ & 28,800 & 34 & 34 & 60,220 & $22 \cdot 9$ & $87 \cdot 5$ & 25,500 & $6 \cdot 4$ & $71 \cdot 6$ \\
\hline $\begin{array}{l}\text { Peak eluted from DEAE } \\
\text { Sephadex column (step 3) }\end{array}$ & 20,000 & 190 & $24 \cdot 6$ & 40,900 & 248 & $59 \cdot 4$ & 12,900 & $5 \mathrm{I} \cdot 4$ & $36 \cdot 2$ \\
\hline $\begin{array}{l}\text { Repeated precipitation from } \\
\text { ammonium sulphate } \\
\text { (step } 4(a) \text { ) }\end{array}$ & 11,700 & 260 & I $3 \cdot 8$ & 18,000 & 330 & $26 \cdot 2$ & $-\cdots$ & $-\cdot$ & - \\
\hline $\begin{array}{l}\text { Peak eluted from DEAE } \\
\text { Sephadex column }(\operatorname{step}(4 b))\end{array}$ & b)) & - & 一 & - & - & - & 2,740 & $82 \cdot 2$ & $7 \cdot 7$ \\
\hline $\begin{array}{l}\text { Peak eluted from Sephadex } \\
\text { G-100 (step }(4 b) \text { ) }\end{array}$ & - & - & - & 一 & - & - & 1,070 & $123 \cdot 5$ & 3 \\
\hline
\end{tabular}

Step $I$. The crude extract was dialysed against several changes of $1.6 \times 10^{-3} \mathrm{M}-$ phosphate buffer, $\mathrm{pH}_{7 \cdot 0}$, and treated with streptomycin as described by Oxenburgh \& Snoswell (1965). The ratio of absorbance at $280 \mathrm{~nm}$. of the centrifuged supernatant liquid increased from $c .0 .55$ to $\mathrm{I} \cdot 4$.

Step 2. The supernatant liquid was dialysed against 0.05 tris- $\mathrm{HCl}$ buffer, $\mathrm{pH} 8$, and applied to a DEAE 50 Sephadex column equilibrated with the same buffer. The D-lactic dehydrogenase was eluted with this same buffer containing $0.2 \mathrm{M}-\mathrm{NaCl}$, and the L-lactic dehydrogenase was subsequently eluted with a linear gradient of $\mathrm{NaCl}$ (between 0.2 and $0.35 \mathrm{M}-\mathrm{NaCl}$ ) in the same buffer.

Step 3. The pool of the most active fractions of the L-lactic dehydrogenase was concentrated on a mechanical membrane concentrator, applied to a Sephadex G-200 column equilibrated with $0.05 \mathrm{M}$-tris- $\mathrm{HCl}$ buffer, $\mathrm{pH} 8$, containing $0 . \mathrm{I} \mathrm{M}-\mathrm{NaCl}$ and eluted with the same solution. The peak fractions were pooled, concentrated using the membrane concentrator, and examined for purity and properties of the enzyme.

Step 4. The D-lactic dehydrogenase eluted from the DEAE Sephadex was precipitated with ammonium sulphate at $90 \%$ concentration and dialysed against $0.05 \mathrm{M}$ phosphate buffer, $\mathrm{pH} 7$. 
Step 5. The preparation from step 4 was applied to a DEAE Sephadex column equilibrated with $0.05 \mathrm{M}$-phosphate buffer, $\mathrm{pH} 7$, and eluted with a linear gradient of $\mathrm{NaCl}$ concentration in the same buffer. The peak of eluted enzyme was obtained with $0 \cdot 12 \mathrm{M}-\mathrm{NaCl}$.

Table 2. Purification of $D$ - and L-lactic dehydrogenases of Lactobacillus acidophilus $65 \mathrm{~K}$

\begin{tabular}{|c|c|c|c|c|c|c|}
\hline \multirow[b]{2}{*}{ Preparations } & \multicolumn{3}{|c|}{ D-Lactic dehydrogenase } & \multicolumn{3}{|c|}{ L-Lactic dehydrogenase } \\
\hline & $\begin{array}{l}\text { Total } \\
\text { activity* } \\
\text { (units) }\end{array}$ & $\begin{array}{c}\text { Specific } \\
\text { activity } \\
\text { (units/mg. } \\
\text { protein) }\end{array}$ & $\begin{array}{l}\text { Yield } \\
(\%)\end{array}$ & $\begin{array}{l}\text { Total } \\
\text { activity* } \\
\text { (units) }\end{array}$ & $\begin{array}{c}\text { Specific } \\
\text { activity } \\
\text { (units/mg. } \\
\text { protein) }\end{array}$ & $\begin{array}{l}\text { Yield } \\
(\%)\end{array}$ \\
\hline Crude extract & 3560 & 0.75 & 100 & 1450 & 0.305 & 100 \\
\hline $\begin{array}{l}\text { Supernatant after strepto- } \\
\text { mycin treatment (step I) }\end{array}$ & 3310 & $\mathrm{I} \cdot 64$ & 93 & 1200 & 0.590 & 83 \\
\hline \multicolumn{7}{|c|}{ DEAE Sephadex at pH 8 (step 2): } \\
\hline $\begin{array}{l}\text { Peak eluted with } \\
0.2 \mathrm{M}-\mathrm{NaCl}\end{array}$ & 2785 & 3.5 & 78 & 0 & - & - \\
\hline $\begin{array}{l}\text { Peak eluted with } \mathrm{NaCl} \\
\text { gradient } 0.20 \text { to } 0.35 \mathrm{M}\end{array}$ & 0 & - & - & 512 & $9 \cdot 75$ & 35 \\
\hline $\begin{array}{l}\text { Peak eluted from Sephadex } \\
\text { G-200 (step 3) }\end{array}$ & - & - & - & 285 & II $\cdot 60$ & $19 \cdot 8$ \\
\hline $\begin{array}{l}\text { Ammonium sulphate ppt. } \\
\text { (60 to } 90 \% \text { saturation: } \\
\text { step } 4)\end{array}$ & 2165 & $7 \cdot 5$ & 6I & - & - & - \\
\hline $\begin{array}{l}\text { Peak eluted from DEAE } \\
\text { Sephadex at pH } 7 \text { (step 5) }\end{array}$ & II 60 & $23 \cdot 6$ & $32 \cdot 6$ & $\cdots$ & - & - \\
\hline $\begin{array}{l}\text { Peak eluted from } \\
\text { Sephadex G-I0o }\end{array}$ & 580 & $38 \cdot 3$ & I6*3 & - & - & - \\
\hline
\end{tabular}

Table 3. Purification of L-lactic dehydrogenase of Lactobacillus acidophilus AI8

\begin{tabular}{|c|c|c|c|}
\hline Preparations & $\begin{array}{c}\text { Total } \\
\text { activity* } \\
\text { (units) }\end{array}$ & $\begin{array}{c}\text { Specific } \\
\text { activity } \\
\text { (units/mg. } \\
\text { protein) }\end{array}$ & $\begin{array}{l}\text { Yield } \\
(\%)\end{array}$ \\
\hline Crude extract & I $\mathrm{I}, \mathrm{I} 2 \mathrm{O}$ & 0.64 & 100 \\
\hline $\begin{array}{l}\text { Ammonium sulphate ppt. (50 to } 70 \% \\
\text { saturation: step I) }\end{array}$ & 9,340 & 0.95 & 84 \\
\hline $\begin{array}{l}\text { Supernatant after streptomycin } \\
\text { treatment (step 2) }\end{array}$ & 8,600 & $2 \cdot 25$ & $77 \cdot 3$ \\
\hline $\begin{array}{l}\text { Peak eluted from DEAE } \\
\text { Sephadex column (step 3) }\end{array}$ & 2,845 & $3 \cdot 3$ & $25 \cdot 6$ \\
\hline $\begin{array}{l}\text { Repeated precipitation from } \\
\text { ammonium sulphate (step 4) }\end{array}$ & 2,770 & $7 \cdot 65$ & $24 \cdot 9$ \\
\hline $\begin{array}{l}\text { Peak eluted from } \\
\text { Sephadex G-100 (step 5) }\end{array}$ & $I, 645$ & $12 \cdot 2$ & I 4.9 \\
\hline
\end{tabular}

Step 6. The pool of the most active fractions was concentrated with a membrane concentrator, applied to a G-IOo Sephadex column, and eluted with the same buffer containing $0 \cdot I \mathrm{M}-\mathrm{NaCl}$. The fractions with the highest activities were concentrated by membrane ultrafiltration and examined for the purity and properties of the enzyme. Results with this procedure are summarized in Table 2. 


\section{Purification of the L-lactic dehydrogenase of Lactobacillus acidophilus AI8}

Step I. Solid ammonium sulphate was slowly added to the crude extract to $50 \%$ saturation. After $2 \mathrm{~h}$. the mixture was centrifuged and the precipitate discarded. The concentration of ammonium sulphate in the supernatant liquid was increased to $70 \%$ saturation by addition of solid ammonium sulphate. After I $2 \mathrm{~h}$., the mixture was centrifuged and the pellet redissolved in $0.05 \mathrm{M}$-phosphate buffer, $\mathrm{pH} 7$, to a concentration of Io $\mathrm{mg}$. protein $/ \mathrm{ml}$.

Step 2. The enzyme preparation was dialysed and treated with streptomycin as described by Oxenburgh \& Snoswell (1965).

Step 3. The enzyme preparation was dialysed against several changes of $0.05 \mathrm{M}$ phosphate buffer, $\mathrm{pH} 7$, and applied to a DEAE Sephadex A 50 column. The column was washed with the same buffer and the enzyme was eluted with a linear gradient of $\mathrm{NaCl}$. The peak tube of eluted enzyme was obtained with $0.12 \mathrm{M}-\mathrm{NaCl}$.

Step 4. The enzyme preparation was submitted to the ammonium sulphate precipitation procedure described in step $4(a)$ for the purification of Lactobacillus leichmannii D-lactic dehydrogenase.

Step 5. The pool of fractions with the highest specific activity were dialysed against $0.05 \mathrm{M}$-phosphate buffer, $\mathrm{pH} 7$, and applied to a G-I00 Sephadex column equilibrated with the same buffer containing $0 \cdot \mathrm{I} \mathrm{M}-\mathrm{NaCl}$. The enzyme was eluted with the same buffer- $\mathrm{NaCl}$ mixture and the peak fractions with equivalent specific activity were pooled. Results with this procedure are summarized in Table 3.

\section{RESULTS AND DISCUSSION}

The results of the purification of the various enzymes are shown in Tables I to 3 .

Criteria of purity. The products of the procedures for the D-lactic dehydrogenases of Lactobacillus leichmannii, L. jensenii and L. fermenti, and for the L-lactic dehydrogenase of $L$. acidophilus A I 8 appeared to be pure, at least by the following three criteria: the constancy of their specific activity on repeated precipitation and on successive extraction with decreasing concentrations of ammonium sulphate; the appearance of a single protein band upon electrophoresis in polyacrylamide gel; and the formation of a single precipitation line with a homologous antiserum in double diffusion and immunoelectrophoresis experiments. The D-lactic dehydrogenase of $L$. acidophilus $65 \mathrm{~K}$ did not appear to be pure and could not be further purified with ammonium sulphate because of its instability. The L-lactic dehydrogenase of the same organism originally showed a single protein band after electrophoresis on polyacrylamide gel. After precipitation with ammonium sulphate, two protein bands were detected, one containing most of the enzymic activity and another diffuse band with a lower migration rate exhibiting only slight activity. Immuno-electrophoresis of a sample of step 6 preparation (Table 2) showed three distinct zones of precipitation with the homologous antiserum.

Although all attempts to obtain well-formed crystals of the enzymes met with failure, the preparations of D-lactic dehydrogenases of Lactobacillus leichmannii, L. jensenii and $L$. fermenti and the L-lactic dehydrogenase of $L$. acidophilus A 8 all showed bi-refringence of flow, characteristic of crystalline enzymes. The D-lactic dehydrogenase preparations consisted predominantly of minute rod-shaped elements from $2 \mu \mathrm{m}$. to several $\mu \mathrm{m}$. in length, sometimes apparently branched. The L-lactic dehydrogenase 
preparation of L. acidophilus strain A I 8 appeared to be more threadlike and somewhat beaded.

Molecular weights. The approximate molecular weights of the enzymes were estimated from their migration in Sephadex G-Ioo columns, using cytochrome $c$, adenosine deaminase, Escherichia coli alkaline phosphatase and ferritin as markers (Whitaker, 1963). All of the D-lactic dehydrogenase enzymes had an apparent molecular weight of $c .80,000$. The L-lactic dehydrogenases from strains A I 8 and $65 \mathrm{~K}$ of Lactobacillus acidophilus had an apparent molecular weight of 120,000 and 125,000 respectively. The molecular weights of the D- and L-lactic dehydrogenases of $L$. plantarum have been previously reported to be 60,000 to 70,000 and 155,000 respectively (Dennis, Reichlin \& Kaplan, 1965).

Table 4. Some properties of $D$ - and L-lactic dehydrogenases of lactobacilli

\begin{tabular}{|c|c|c|c|c|c|c|c|c|}
\hline & \multicolumn{5}{|c|}{$\begin{array}{c}\text { D-Lactic } \\
\text { dehydrogenase }\end{array}$} & \multicolumn{3}{|c|}{$\begin{array}{c}\text { L-Lactic } \\
\text { dehydrogenase }\end{array}$} \\
\hline & 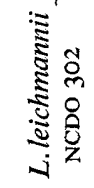 & 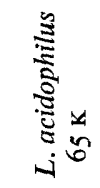 & 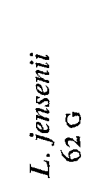 & 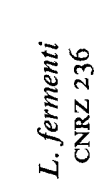 & 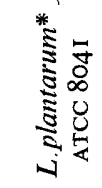 & 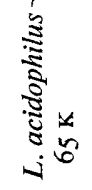 & 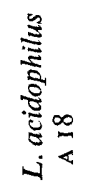 & 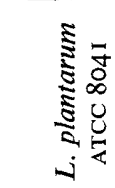 \\
\hline \multicolumn{9}{|c|}{ (Rate for lactate $\rightarrow$ pyruvate) $; \mathrm{pH} 8$} \\
\hline \multicolumn{9}{|c|}{$\begin{array}{l}\text { Specificity: relative rates with } \\
\text { substituted substrates: } \dagger\end{array}$} \\
\hline (a) $\alpha$-Oxobutyrate & 0.02 & 0 & o & 0.07 & 0.25 & 0.13 & 0.19 & 0.25 \\
\hline (b) Deamino-NAD & $\mathbf{I} \cdot 00$ & 0 & 0.55 & 0.28 & 0.60 & 0 & 0.09 & 0 \\
\hline (c) 3-Acetylpyridine NAD & 0.43 & $1 \cdot 50$ & 0.46 & $1 \cdot 00$ & $4 \cdot 30$ & $16 \cdot 5$ & $2 I \cdot 6$ & $13 \cdot 0$ \\
\hline (d) Pyridine-3-aldehyde NAD & o & 0 & 0 & $\circ$ & 0.07 & 0.24 & 0 & 0.57 \\
\hline \multicolumn{9}{|l|}{ pH Optimum in tris-maleate } \\
\hline (b) Pyruvate $\rightarrow$ lactate & $7 \cdot 6$ & $7 \cdot 3$ & $7 \cdot 8$ & $8 \cdot 6$ & - & $5 \cdot 3$ & $5 \cdot 3$ & - \\
\hline \multicolumn{9}{|l|}{$\frac{(\text { Rate in tris-maleate) }}{\text { (Rate in tris- } \mathrm{HCl})} ; \mathrm{pH} 8$} \\
\hline (a) Lactate $\rightarrow$ pyruvate & 0.65 & $\mathrm{I} \cdot 07$ & $1 \cdot 04$ & 0.76 & 一 & 0.94 & $I \cdot 84$ & - \\
\hline (b) Pyruvate $\rightarrow$ lactate & 0.58 & $2 \cdot 30$ & $\mathbf{I} \cdot 3 \mathbf{I}$ & 0.77 & - & $1 \cdot 73$ & $2 \cdot 40$ & - \\
\hline \multicolumn{9}{|l|}{$K_{m}$ at optimal pH (tris-maleate) } \\
\hline (a) Lactate $\left(\mathrm{M} \times 1 \mathrm{O}^{-1}\right)$ & 0.7 & I $2 \cdot 5$ & 0.7 & 0.2 & 0.2 & $3 \cdot 6$ & $16 \cdot 6$ & 0.6 \\
\hline (b) Pyruvate $\left(\mathrm{M} \times 1 \mathrm{O}^{-3}\right)$ & $I \cdot 2$ & $4 \cdot 6$ & $7 \cdot 2$ & $1 \cdot 9$ & $4 \cdot 7$ & $1 \cdot 5$ & $2 \cdot 7$ & 0.37 \\
\hline (c) NADH $\left(\mathrm{M} \times 1 \mathrm{IO}^{-5}\right)$ & $7 \cdot 1$ & $16 \cdot 0$ & $16 \cdot 6$ & $10 \cdot 0$ & - & $6 \cdot 9$ & $7 \cdot 4$ & - \\
\hline \multicolumn{9}{|l|}{$\begin{array}{l}\text { Heat inactivation: } \% \text { activity } \\
\text { destroyed after } 5 \mathrm{~min} \text {. at: }\end{array}$} \\
\hline (a) $45^{\circ}$ & 0 & 98 & 0 & 54 & - & 0 & 0 & 0 \\
\hline (b) $50^{\circ}$ & 50 & 100 & 25 & 98 & 100 & 0 & 0 & 0 \\
\hline (c) $80^{\circ}$ & 100 & 100 & 100 & 100 & 100 & 50 & 20 & $>92$ \\
\hline
\end{tabular}

* Previously reported data for L. plantarum enzymes are shown for comparison (Dennis \& Kaplan, I960; Dennis, Reichlin \& Kaplan, 1965), but the conditions for some assays were not identical with those employed in the present studies.

$\uparrow$ As compared with rates for pyruvate and NADH or lactate and NAD.

The D-lactic dehydrogenases of Lactobacillus leichmannii and L. fermenti appeared to be homogeneous in the ultracentrifuge and exhibited monodisperse peaks. Using conditions described in Methods, and $7.8 \mathrm{mg}$. protein $/ \mathrm{ml}$, the sedimentation co- 
efficient $\left(S_{20},{ }_{w}\right)$ of the L. leichmannii enzyme was calculated to be 3.9 s. For the $L$. fermenti enzyme (Io mg./ml.), the sedimentation coefficient was $4 \cdot 4 \mathrm{~s}$. Because of the unexpectedly low sedimentation coefficient of the L. leichmannii enzyme, its apparent molecular weight was determined by the short column sedimentation equilibrium technique (van Holde \& Baldwin, 1958) using protein concentrations of $0.125,0.25$, $0.5, \mathrm{I} \cdot 0$ and $\mathrm{I} .5 \mathrm{mg} . / \mathrm{ml}$. The molecular weight, extrapolated to zero concentration, was found to be $c .68,000$ ( $\bar{v}$ used for calculations, 0.74 ).

Specificity. The relative rate of NADH oxidation with pyruvate to that of NAD reduction with lactate was determined for each enzyme (Table 4 (I)) at $\mathrm{pH} 8$ in tris- $\mathrm{HCl}$ buffer (see Methods). The specificity of the enzymes (Table 4 (2)) was tested under the usual assay conditions at $\mathrm{pH} 8$. $\alpha$-Oxobutyrate was substituted for pyruvate with NADH as hydrogen donor (no reaction between NAD and either DL-hydroxybutyrate or DL- $\alpha$-hydroxy- $\alpha$-methylbutyrate was detected with any enzyme). NADH was oxidized with $\alpha$-oxoglutarate at one-tenth the rate observed with pyruvate by the D-lactic dehydrogenase of Lactobacillus acidophilus $65 \mathrm{~K}$; this might have been due to an impurity in this preparation.

Analogues of NAD were assayed at $2 \times 10^{-3} \mathrm{M}$ concentration with $\mathrm{D}(-)$ or $\mathrm{L}(+)$ lactate as substrate. Nicotinamide adenine dinucleotide phosphate (NADP) was not reduced by any of the enzymes tested. The relative rates of reduction of other NAD analogues (Table 4 (2)) were computed by using the following wavelengths and molar extinction coefficients: deamino-NAD, $340 \mathrm{~nm} ., 6 \cdot 2 \times 10^{3}$; pyridine-3-aldehyde NAD, $355 \mathrm{~nm} ., 9 \cdot 3 \times 10^{3} ; 3$-acetylpyridine NAD, $365 \mathrm{~nm} ., 9 \cdot 1 \times \mathrm{IO}^{3}$.

pH Optima and kinetic properties. The apparent optimal $\mathrm{pH}$ for the oxidation of lactate and the reduction of pyruvate was determined for each enzyme in tris-maleic acid-sodium maleate buffers (Table 4 (3)). As seen in Table 4 (4), the choice of buffer not only had different effects on different enzymes but also had different and sometimes opposite effects on the reaction rates of a given enzyme catalysing the same reaction in opposite directions. These observations have not been elucidated and the explanation may be complex, since the maleate buffer differs from the chloride buffer not only in the nature of its anion and the corresponding acid, but also in its sodium content and ionic strength.

The $K_{m}$ values for lactate, pyruvate and NADH (see Methods) are shown in Table 4 (5). The determination of $K_{m}$ value for NAD was impracticable. The D- and L-lactic dehydrogenases of Lactobacillus plantarum (Dennis \& Kaplan, I960) and those described in this article showed linear kinetic responses in double reciprocal plot. Butyribacterium rettgeri and Escherichia coli D-lactic dehydrogenases exhibited sigmoidal kinetics with respect to pyruvate (Wittenberger \& Fulco, 1967; Tarmy \& Kaplan, I968). No such effect was found with lactic dehydrogenases of lactobacilli.

Activators and inhibitors. The effect of the different buffers on the rate of reaction has already been mentioned. Several compounds were tested for inhibitory or activating effects on the oxidation of pyruvate and reduction of lactate. Neither EDTA $\left(\mathrm{IO}^{-3} \mathrm{M}\right)$ nor fructose- $I-6$-diphosphate $\left(\mathrm{IO}^{-2} \mathrm{M}\right)$ had any effect. This last compound is required for the activity of the L-lactic dehydrogenases of Streptococcus bovis (Wolin, I964), Bifidobacterium bifidum (de Vries, Gerbrandy \& Stouthamer, 1967) and Streptococcus faecalis (C. L. Wittenberger, personal communication). Oxamate, which has been shown to inhibit strongly the D- and L-enzymes of Lactobacillus plantarum at concentrations below $10^{-3}$ M (Dennis \& Kaplan, 1960), had no effect on any of the enzymes 
studied in the present work at $5 \times 10^{-3} \mathrm{M}$. At $1 \mathrm{I}^{-2} \mathrm{M}$ concentration, oxamate had a slight inhibitory effect ( 15 to $25 \%$ ) on the three enzymes obtained from the two strains of $L$. acidophilus.

Adenosine triphosphate (ATP) is an allosteric effector for the D-lactic dehydrogenase of Butyribacterium rettgeri (Wittenberger, I968). In our study, neither ATP, ADP nor AMP $\left(5 \times \mathrm{IO}^{-3} \mathrm{M}\right)$ had any effect on the activity of the lactic dehydrogenases, except for the L-lactic dehydrogenases of Lactobacillus acidophilus. For the enzyme of L. acidophilus strain A I8, all three compounds were somewhat inhibitory in the oxidation of lactate (AMP, $50 \%$; ADP, $21 \%$; ATP, $28 \%$ inhibition) but increased the rate of pyruvate reduction by 5 to $10 \%$. With the enzyme of L. acidophilus $65 \mathrm{~K}$, AMP reduced the rate of enzyme action in both directions by $c .30 \%$; ADP increased only the rate of lactate oxidation by $22 \%$, while ATP was without any effect. The above results cannot be meaningfully interpreted in terms of specific control mechanisms and may be due to fortuitous side effects of the addition of relatively large quantities of the compounds in question.

The observations reported here show that, while the D-lactic dehydrogenases of different species of Lactobacillus have certain properties in common, they are readily distinguishable from each other on the basis of their physical and catalytic properties. The L-lactic dehydrogenases, which also show certain resemblances to each other, differ in several respects (e.g. their molecular weights and thermal stability) from the D-enzymes. As will be shown in a subsequent paper, the D-lactic dehydrogenases are also immunologically distinct from the L-enzymes and immunological cross-reactions are demonstrable among the enzymes of each type obtained from different species.

This investigation was supported in part by U.S. Public Health Service grant AI-1 808 from the National Institute of Allergy and Infectious Diseases, and in part by National Science Foundation grant GB-4II2. The travel expenses of the senior author were defrayed by a Fulbright grant, P.L. 87256 . We are grateful to Miss Ruthe Wayner for the ultracentrifugation analyses.

\section{REFERENCES}

DAvis, B. J. (I964). Disc electrophoresis. II. Method and application to human serum proteins. Annals of the New York Academy of Sciences 121, 404-427.

Dennis, D. \& KaPlan, N. O. (1960). D- and L-Lactic dehydrogenases in Lactobacillus plantarum. Journal of Biological Chemistry 235, 810-8I 8.

Dennis, D., Reichlin, M. \& Kaplan, N. O. (1965). Lactic acid racemization. Annals of the New York Academy of Sciences $\mathbf{x I 9}, 868-876$.

GASSER, F. (1970). Electrophoretic characterization of lactic dehydrogenases in the genus Lactobacillus. Journal of General Microbiology 62, 223-239.

Grabar, P. \& Williams, C. A. (I955). Méthode immuno-électrophorétique d'analyse de mélanges de substances antigéniques. Biochimica et Biophysica Acta r7, 67.

vaN Holde, K. E. \& Baldwin, R. L. (I958). Rapid attainment of sedimentation equilibrium. Journal of Physical Chemistry 62, 734-743.

LINEWEAVER, H. \& BURK, D. (I934). The determination of enzyme dissociation constants. Journal of the American Chemical Society 56, 658-666.

Lowry, O. H., Rosebrough, N. J., FARr, A. L. \& Randall, R. J. (195I). Protein measurement with the Folin phenol reagent. Journal of Biological Chemistry 193, 265-275.

Oxenburgh, M.S. \& SNoswell, A. M. (1965). Use of streptomycin in the separation of nucleic acids from protein in a bacterial extract. Nature, London 207, I4I6-1417. 
TARMY, E. M. \& KAPLAN, N. O. (1968). Kinetics of Escherichia coli B D-lactate dehydrogenase and evidence for pyruvate-controlled change in conformation. Journal of Biological Chemistry $\mathbf{2 4 3}$, 2587-2596.

De Vries, W., Gerbrandy, S. J. \& Stouthamer, A. H. (1967). Carbohydrate metabolism in Bifidobacterium bifidum. Biochimica et Biophysica Acta 136, 415-425.

WhITAKER, J. R. (1963). Determination of molecular weights of proteins by filtration on Sephadex. Analytical Chemistry 35, 1950-1953.

WITTENBERGER, C. L. (1968). Kinetic studies of the inhibition of a D (-) specific lactate dehydrogenase by adenosine triphosphate. Journal of Biological Chemistry 243, 3067-3075.

Wittenberger, C. L. \& FulCo, J. G. (1967). Purification and allosteric properties of a nicotinamide adenine dinucleotide-linked D (-) specific lactate dehydrogenase from Butyribacterium rettgeri. Journal of Biological Chemistry 242, 2917-2924.

Wolin, M. J. (1964). Fructose 1-6-diphosphate requirement of streptococcal lactic dehydrogenases. Science, New York r46, 775-776. 